\title{
MENTALNOŚĆ I MORALNOŚĆ PODATKOWA A REAKCJE GOSPODARSTW DOMOWYCH NA OBOWIĄZEK PODATKOWY
}

\begin{abstract}
Podatek w swej konstrukcji wymusza przejmowanie części dochodu lub majątku gospodarstw domowych, przez co często postrzegany jest jako świadczenie ograniczające konsumpcję, inwestycję oraz wolność jednostki. Pozbawiony waloru neutralności podatek generuje skutki gospodarcze i społeczne, a przez to w istotny sposób determinuje zachowania uczestników rynku. Elementy techniki podatkowej tj. podmiot, przedmiot, wysokość stawki, ulgi i zwolnienia wpływają na reakcje gospodarstw domowych względem zobowiązań podatkowych. Rozwój cywilizacyjny, przyspieszony postęp nauki i techniki doprowadził z jednej strony do poprawy warunków ekonomicznych życia współczesnych społeczeństw, $\mathrm{z}$ drugiej strony podkreśla się także zauważalny spadek moralności obywateli. Do pozaekonomicznych czynników wpływających na zachowania podatników można zaliczyć natomiast tradycje regionalne, czynniki ze sfery psychologicznej oraz moralność i mentalność społeczeństwa.

Podatek jako świadczenie przymusowe, bezzwrotne i nieekwiwalentne zawsze stanowi ograniczenie konsumpcji podatnika i rodzi uczucie niezadowolenia. W artykule scharakteryzowano postawy podatników oraz przesłanki pozaekonomiczne mogące wpływać na reakcje gospodarstw domowych względem obowiązku podatkowego. W literaturze najczęściej wyróżnia się sześć reakcji podatników na obciążenie fiskalne: spełnienie obowiazku podatkowego, przerzucanie podatku, legalne unikanie podatku, nadrobienie, nielegalne uchylanie się od podatku oraz wycofywanie się z działalności objętej daniną. Najkorzystniejsze dla administracji fiskalnej jest dostosowanie się do podatku. Celem artykułu jest zaprezentowanie istoty moralności i mentalności podatkowej Polaków oraz ich wpływu na skłonność do oszustw podatkowych gospodarstw domowych.
\end{abstract}

Słowa kluczowe: moralność podatkowa, mentalność podatkowa, oszustwa podatkowe

\section{WPROWADZENIE}

Podatek w swej konstrukcji wymusza przejmowanie części dochodu lub majątku gospodarstw domowych, przez co często postrzegany jest jako świadczenie ograniczające konsumpcję, inwestycję oraz wolność jednostki. Pozbawiony waloru neutralności podatek generuje skutki gospodarcze i społeczne, a przez to istotnie determinuje zachowania uczestników rynku. Elementy techniki podatkowej, czyli podmiot, przedmiot, wysokość stawki, ulgi i zwolnienia, wpływają na reakcje gospodarstw domowych względem zobowiązań podatkowych. Przesłankami ekonomicznymi są także: koniunktura gospodarcza, indywidualna sytuacja majątkowa podatnika, intensywność regulacji oraz nadmierna ingerencja państwa w kwestii regulacji rynku.

Do pozaekonomicznych czynników wpływających na zachowania podatników można zaliczyć natomiast tradycje regionalne, czynniki ze sfery psychologicznej oraz moralność i mentalność społeczeństwa.

Rozwój cywilizacyjny, przyspieszony postęp nauki i techniki doprowadziły z jednej strony do poprawy warunków ekonomicznych życia współczesnych społeczeństw, z drugiej strony podkreśla się także zauważalny spadek moralności obywateli. Celem artykułu

\footnotetext{
${ }^{1}$ Dr Monika Pasternak-Malicka, Zakład Finansów i Bankowości, Wydział Zarządzania, Politechnika Rzeszowska, al. Powstańców Warszawy 8, 35-959 Rzeszów, tel. 17 8651912, e-mail: m.k.maliccy@neostrada.pl.
} 
jest zaprezentowanie istoty moralności i mentalności podatkowej Polaków oraz ich wpływu na skłonność do oszustw podatkowych gospodarstw domowych.

\section{REAKCJE PODATNIKÓW NA OBOWIĄZEK PODATKOWY}

Konsekwencją ingerencji państwa w stosunki majątkowe są reakcje podatników na opodatkowanie. Mechanizmem uruchamiającym konkretne zachowania są postawy wobec podatków. Są one różne - począwszy od osób uczciwych, płacących podatki, a skończywszy na nieuczciwych, które od ich płacenia świadomie lub nieświadomie uciekają. Zdecydowana większość podatników, jeżeli takimi możliwościami dysponuje, aktywnie broni się przed obciążeniami podatkowymi.

Pietrewicz wyróżnia sześć reakcji podatników: ${ }^{2}$

- dostosowanie się do podatku, czyli spełnienie obowiązku podatkowego,

- przerzucanie podatku,

- legalne unikanie podatku,

- nadrobienie podatku,

- nielegalne uchylanie się od podatku,

- wycofywanie się z działalności będącej przedmiotem opodatkowania.

Subiektywne przekonanie podatników, że płacone przez nich daniny są zbyt wysokie, prowadzi do podejmowania działań, które mają na celu maksymalne ograniczenie wysokości obciążeń fiskalnych. Jeśli zachowania te przybierają dozwoloną przez prawo postać i są związane z wykorzystaniem luk w prawie podatkowym, określa się je wówczas jako unikanie podatków, jeśli zaś są niezgodne z prawem - uchylanie się od opodatkowania ${ }^{3}$.

$\mathrm{Na}$ zjawisko to mają wpływ uwarunkowania ekonomiczne i psychologiczne, przy czym oba czynniki są wzajemnie zależne - opodatkowanie napotyka granicę psychologiczna, gdy ciężar podatkowy sprawia, że efekt opodatkowania nie jest realizowany w zakładanej wysokości ${ }^{4}$. Reakcje podatników zależą od tego, w jakiej formie i wysokości mają zapłacić podatek. Niechęć do regulowania zobowiązań podatkowych według Gwiazdowskiego szczególnie potęguje progresywna forma opodatkowania ${ }^{5}$.

Zdaniem badaczy sposób traktowania podatników i możliwość współdecydowania w kwestiach fiskalnych sprawiają, że rozwija się poczucie obowiązku obywatelskiego, związanego z mentalnością i moralnością podatkową.

Według Strümpla zgoda na płacenie podatków zależy od dwóch kategorii czynników: surowości systemu oraz chęci współpracy. Pierwszy z nich obejmuje takie elementy, jak suma płaconych podatków, efektywność aparatu skarbowego oraz obowiązujące w danym kraju sankcje karno-skarbowe. Na drugi czynnik składają się indywidualne oceny systemu podatkowego oraz zajmowane postawy wobec podatków. Czynnik ten decyduje o mentalności podatkowej danego kraju ${ }^{6}$.

${ }^{2}$ M. Pietrewicz, Polityka fiskalna, Warszawa 1993, s. 65-66.

${ }^{3}$ J. Głuchowski, Polskie prawo podatkowe, LexisNexis, Warszawa 2006, s. 158-159. Czesto wykorzystywanym pojęciem określającym unikanie podatków jest optymalizacja podatkowa. Takie działanie podatnika ma doprowadzić do oszczędzania podatkowego. Por. J. Grzywacz, Pranie pieniędzy. Metody. Raje Podatkowe. Zwalczanie, Oficyna Wydawnicza SGH, Warszawa 2011, s. 59.

${ }^{4}$ A. Gumułowicz, Zasada sprawiedliwości podatkowej, Dom Wydawniczy ABC, Warszawa 2001, s. 82.

${ }^{5}$ R. Gwiazdowski, Podatek progresywny i proporcjonalny. Doktrynalne przestanki, praktyczne konsekwencje, Wydawnictwo Uniwersytetu Warszawskiego, Warszawa 2007, s. 225.

${ }^{6}$ M. Niesiobędzka, Relacje podatnik-państwo jako predykatory moralności podatkowej, „Psychologia Społeczna”, 4/3, red. M. Lewicka, Polskie Stowarzyszenie Psychologii Społecznej, Warszawa 2009, s. 124. 


\section{MENTALNOŚĆ PODATKOWA}

$\mathrm{Na}$ zachowanie gospodarstw domowych w poważnym stopniu mają wpływ czynniki moralne związane z etyką oraz stanem świadomości społeczeństwa. W literaturze rozgranicza się dwa pojęcia opisujące stosunek obywateli do płacenia podatków: mentalność i moralność podatkową ${ }^{7}$.

Mentalność podatkowa stanowi obszar świadomości społecznej, stosunku do obowiązków obywatelskich. Można ją określić jako zbiorową reakcję społeczną na opodatkowanie $^{8}$. Jest to postawa wobec obciążeń fiskalnych reprezentowana przez określoną grupe społeczną ${ }^{9}$. Mentalność definiuje się także jako nastawienie wobec opodatkowania reprezentowane przez grupę społeczną, z którą podatnik się utożsamia i do której należy ${ }^{10}$.

Społeczeństwo bardziej rygorystycznie podchodzi do przestrzegania norm dotyczących życia prywatnego niż do życia publicznego, czyli łamanie norm publicznych jest mniej naganne niż naruszanie zasad życia prywatnego ${ }^{11}$. Sprzyja temu słaba pozycja podatnika względem państwa oraz rygorystyczna polityka fiskalna.

W przekroju regionalnym można zaobserwować zmienną skalę zachowań w zakresie uzyskiwania dochodów nierejestrowanych. Jednym z czynników różnicujących te zachowania są przyzwyczajenia wynikające $\mathrm{z}$ tradycji regionalnych ${ }^{12}$. Z kolei czynniki o charakterze psychologicznym powodują dążenie do bogacenia się w szybkim tempie i za wszelką cenę ${ }^{13}$.

W literaturze przedmiotu zauważa się geograficzne różnice reakcji na opodatkowanie. Dlatego wyodrębnia się kraje o mentalności południowej i północnej ${ }^{14}$. W krajach zaliczanych do pierwszej grupy (Grecja, Włochy, Hiszpania) wystęują trudności ze ściaganiem zobowiązań podatkowych, a przede wszystkim podatków bezpośrednich (dochodowych i majątkowych). Podatki pośrednie nie spotykają się z tak wyraźną niechęcią. Natomiast kraje o mentalności północnej (kraje skandynawskie, Niemcy) charakteryzują się dużą dyscypliną podatkową. Wiele wskazuje na to, że znaczna część Polaków ma południową mentalność. Wpłynęły na to czynniki o różnorodnym charakterze, takie jak fakt, że przez wiele lat społeczeństwo polskie nie płaciło podatków od dochodów indywidual-

\footnotetext{
${ }^{7}$ B. Mróz, Gospodarka nieoficjalna w systemie ekonomicznym, Szkoła Główna Handlowa, Warszawa 2002, s. 39.

${ }^{8}$ A. Komar, Finanse publiczne w gospodarce rynkowej, Oficyna Wydawnicza Branta, Bydgoszcz 1996, s. 137.

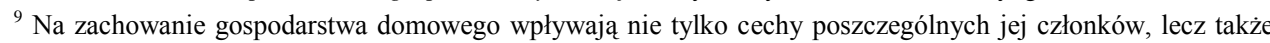
jego miejsce w przestrzeni społecznej. Każdy człowiek wchodzi w skład określonej grupy społecznej, definiowanej jako zbiór osób kontaktujących się ze sobą dla osiągnięcia określonego celu o charakterze indywidualnym i/lub zbiorowym. Członkowie grupy są połączeni, świadomie lub nieświadomie, więzami psychicznymi, wyrażającymi się identycznymi lub podobnymi przekonaniami, systemem wartości i normami, które są podstawowymi regulatorami ich zachowań wewnątrz grupy i w stosunku do otoczenia zewnętrznego. Por. Cz. Bywalec, Ekonomika i finanse gospodarstw domowych, PWN, Warszawa 2012, s. 50-51.

${ }^{10}$ A. Gomułowicz, J. Małecki, Podatki i prawo podatkowe, LexisNexis, Warszawa 2004, s. 237.

${ }^{11}$ P. Gaudemet, Finanse publiczne, PWE, Warszawa 2000, s. 576-577.

${ }^{12}$ A. Kozłowicz, H. Mruk, G. Nowaczyk, Przyczyny i konsekwencje drugiego obiegu dochodów, „Gospodarka Planowa" 1987/6, s. 263.

${ }^{13}$ Z. Sufin, Społeczne uwarunkowania i konsekwencje kryzysu, „Nowe Drogi” 1980/12, s. 70.

${ }^{14}$ Podział ten powoli się zaciera. Oszustwa podatkowe zaczynają przenikać zarówno kraje południa, jak i północy. Podkreśla się także, że większa uczciwość podatkowa w krajach północy zależy w dużej mierze od sprawnej administracji podatkowej, zwłaszcza w zakresie wymiaru i poboru podatków. Por. A. Gomułowicz, J. Małecki, op. cit., s. 242.
} 
nych. Istotny jest także stosunek ludzi do władzy państwowej i obowiązków obywatelskich $^{15}$

Wśród przyczyn występowania na szeroką skalę zjawiska uchylania się od opodatkowania w niektórych krajach Europy Środkowej i Wschodniej wskazuje się nieprzezwyciężone jeszcze w pełni dziedzictwo przeszłości w postaci niechętnego podejścia różnych grup społecznych do płacenia podatków. Postawy te uzasadnia się między innymi wysokim stopniem korupcji w urzędach i instytucjach publicznych oraz negatywną oceną jakości i dostępności usług finansowanych ze środków publicznych ${ }^{16}$. Elementy te wpływają na kształtujący się latami tak zwany charakter podatkowy, charakteryzujący się utrzymującym się w wielu grupach społecznych cichym przyzwoleniu dla niepłacenia podatków ${ }^{17}$.

Postawy społeczne wobec nielegalnych działań są uwarunkowane historycznie. Ogromna szara strefa to po części rezultat braku „instynktu państwowego” obywateli. W Polsce płacenia podatków nigdy nie kojarzono z interesem państwa, obywatele nie czuli z państwem specjalnego związku. W okresie realnego socjalizmu oszustwa podatkowe uważano wręcz za działania antysystemowe, przejaw zaradności. Podobne zjawisko można zaobserwować we Włoszech, gdzie według Marroniego „są dziesięciolecia złych tradycji i stulecia braku zaufania do państwa" ${ }^{18}$, a także uchylanie się od opodatkowania postrzegane jest jako moralny obowiązek ${ }^{19}$

Zakres gospodarki nieformalnej w dużej mierze zależy od stopnia poparcia nielegalnych działań w społeczeństwie ${ }^{20}$. W Rosji, gdzie istnieje potężne państwo równoległe, coraz więcej obywateli akceptuje, a nawet pochwala zasady obowiązujące w szarej strefie, uznaje je za swoje i uważa je za bardziej ludzkie niż prawo, które usiłuje im narzucić państwo $^{21}$

Na mentalność podatkową mają wpływ także uwarunkowania związane ze zmianą ustroju i systemu gospodarczego państwa, wywołujące skutki dla poczucia państwowości, utożsamiania się z władzą, przestrzegania konstytucyjnych standardów przy tworzeniu systemu podatkowego ${ }^{22}$.

\section{MORALNOŚĆ PODATKOWA}

Pojęcie moralności podatkowej wprowadził w 1960 roku Schmöders, definiując je jako ,postawy grupy lub całej populacji podatników dotyczące kwestii wywiązywania się lub zaniedbywania obowiązków podatkowych utrwalonej w mentalności podatkowej i świadomości obywatelskiej”,23. Obecnie moralność rozumiana jest jako wewnętrzna motywacja do płacenia podatków ${ }^{24}$.

\footnotetext{
${ }^{15}$ A. Krajewska, Podatki. Unia Europejska, Polska, Kraje Nadbattyckie, PWE, Warszawa 2004, s. 234, 247.

${ }^{16}$ L. Oręziak, Konkurencja podatkowa i harmonizacja podatków w ramach Unii Europejskiej. Implikacje dla Polski, WSHiP w Warszawie, Warszawa 2007, s. 23.

${ }^{17}$ A. Gołdyn, Przyczyny ucieczki przed podatkiem, „Monitor Podatkowy” 1996/6, s. 5.

${ }^{18}$ J. Piński, K. Trębski, Zrobieni na szaro, „Wprost” 2003/5, s. 41.

${ }^{19}$ S. James, C. Nobes, The economics of Taxation, Philip Allan, Oxford 1988, s. 117.

${ }^{20}$ M. Wiśniewski, Źródła i rozmiary drugiego obiegu gospodarczego w Polsce, ,Ekonomista” 1985/6, s. 915.

${ }^{21}$ I. Kliamkin, L. Timofiejew, Szara strefa w Rosji, Cyklady, Warszawa 2003, s. 8.

${ }^{22}$ E. Bogacka-Kisiel, Finanse osobiste. Zachowania - produkty - strategie, PWN, Warszawa 2012, s. 302-303.

${ }^{23}$ E. Kichler, The economic psychology of tax behaviour, Cambridge University Press, Cambridge 2007, s. 99.

${ }^{24} \mathrm{~J}$. Alm, B. Torgler, Culture differences and tax morale in the United States and in Europe, ,Journal of Economic Psychology", Amsterdam 2006, 27, s. 228.
} 
Moralność podatnika polega na indywidualnej reakcji danej osoby na obciążenia podatkowe ${ }^{25}$. Wymaga ona, aby działanie podatnika odpowiadało jego wewnętrznemu przekonaniu, dlatego też można traktować ją jako wewnętrzną akceptację (bądź jej brak) obowiązku podatkowego oraz uznania zwierzchności fiskalnej państwa ${ }^{26}$.

W literaturze moralność podatkowa nazywana jest także etyką podatnika, którą określa się jako zbiór norm moralnych przyjętych $\mathrm{w}$ danej zbiorowości i dotyczących postawy podatnika względem wnoszenia obowiązkowych opłat do budżetu państwa ${ }^{27}$.

W języku potocznym pojęcie „etyka” i „moralność” bywają utożsamiane i używane zamiennie, nie są to jednak terminy tożsame. Oba odnoszą się do przestrzegania ustalonych i obowiązujących w danym społeczeństwie norm postępowania, lecz etyka to nauka o moralności, naukowa refleksja nad moralnością.

Moralność podatkowa odnosi się do indywidualnych reakcji na opodatkowanie, czyli sięga do sumienia podatnika. Podatek wpływa nie tylko na zmniejszenie konsumpcji, lecz w pewnym sensie, w wypadku osób fizycznych, na ograniczenie ich praw podmiotowych. Dlatego należy mieć świadomość, że podatkowi towarzyszy skłonność do uchylania się od niego. Pomysłowość podatników jest w tym zakresie niezwykle rozwinięta i może mieć formę legalnego lub nielegalnego uchylania się od płatności fiskalnych ${ }^{28}$.

Przy czym należy zaznaczyć różnicę między moralnością a uchylaniem się od płacenia podatków. Uchylanie się od podatku jest zachowaniem jednostki a moralność podatkowa postawą ${ }^{29}$. Niemniej jednak poziom moralności podatkowej wywiera silny wpływ na zachowanie podatników, w tym również na skalę oszustw podatkowych. Oszacowano, że obniżenie moralności podatkowej o jedną jednostkę prowadzi do wzrostu rozmiarów szarej strefy o ponad $20 \%{ }^{30}$.

Na moralność podatkowa gospodarstw domowych wpływają takie elementy, jak: budowa systemu podatkowego ${ }^{31}$, sposób postępowania administracji podatkowej, uzyskiwana efektywność kontroli ${ }^{32}$.

Socjalno-psychologicznym aspektem uchylania się od płacenia podatków jest problem oceny priorytetu. Wielu przedsiębiorców twierdzi, że rola działalności gospodarczej w społeczeństwie ma wyłącznie wymiar ekonomiczny. Uważają, że „biznes powinien tworzyć tylko wysokie dochody. To wszystko, czego się od niego wymaga, bez podawania metod osiagnnięcia tego efektu. W biznesie etyka nie jest głównym motywem działania, zwłaszcza że bardzo często staje się przeszkodą do osiągnięcia celów"33.

\footnotetext{
${ }^{25}$ E. Bogacka-Kisiel, op. cit., s. 303.

${ }^{26}$ A. Gomułowicz, J. Małecki, op. cit., s. 242.

${ }^{27}$ A. Szulc, Przyczyny i skutki zatrudnienia nierejestrowanego w Polsce, Cedetu, Warszawa 2013, s. 91-92.

${ }^{28}$ A. Komar, op. cit., s. 137.

${ }^{29}$ F. Schneider, B. Torgler, Shadow Economy, Tax Morale, Governance and Institutional Quality: A Panel Analysis, „IZA Discussion Paper Series” 2007/2541, s. 6.

${ }^{30}$ B. Torgler, Tax Compliance and Tax Morale. A Theoretical and Empirical Analysis, Edward Elgar Publishing Limited, Cheltenham 2007, s. 191.

${ }^{31}$ Say sformułował zasadę, zgodnie z którą należy nakładać tylko takie podatki, które są „,raczej zgodne aniżeli sprzeczne z moralnością, to znaczy ze zwyczajami pożytecznymi dla społeczeństwa”. Por. G. Szczodrowski, Polski system podatkowy, PWN, Warszawa 2007, s. 38-39.

${ }^{32}$ A. Gomułowicz, Polityka podatkowa w Polsce i przestanki jej ksztaltowania, „Monitor Podatkowy” 1996/5.

${ }^{33}$ I. Taranow, Socjalno-psychologiczne aspekty uchylania się od podatków na Ukrainie, „Studia i Prace KZiF”, z. 22, SGH, Warszawa 2001, s. 131.
} 


\section{MORALNOŚĆ PODATKOWA A BADANIA EMPIRYCZNE}

Badania nad problemem moralności podatkowej w aspekcie empirycznym są zagadnieniem niezwykle trudnym i złożonym. W państwach, w których prowadzone były badania, odpowiedzi podatników wskazywały, że ocena oszustw podatkowych jest w odbiorze społecznym neutralna bądź całkiem łagodna. Respondenci uważali, że przy obliczaniu podatku należy stosować działania na pograniczu prawa, aby zminimalizować obciążenie podatkowe ${ }^{34}$.

Z przeprowadzonych w 2005 r. badań wynika, że moralność podatkowa gospodarstw domowych w Stanach Zjednoczonych jest znacznie wyższa niż w Hiszpanii, a także w 14 innych badanych krajach europejskich. Analiza ta wykazała także silną negatywną korelację pomiędzy wielkością szarej strefy a poziomem moralności podatkowej - im wyższa moralność podatkowa, tym zakres szarej strefy niższy ${ }^{35}$.

Mimo że podkreśla się, że Amerykanie są tradycyjnie uczciwymi podatnikami, to moralność podatkowa w tym kraju ucierpiała na skutek słabnącej koniunktury, restrykcyjnych przepisów fiskalnych oraz narastających wątpliwości na temat sprawiedliwości systemu podatkowego. Płacący podatki obywatele przestali wierzyć, że w zamian otrzymają od państwa świadczenia w postaci rozwoju infrastruktury, ochrony zdrowia i zabezpieczenia emerytalnego ${ }^{36}$.

Z badań dotyczących Szwajcarii wynika, że w kraju tym podatników i władze publiczne łączy swego rodzaju ,psychologiczna umowa podatkowa” skłaniająca ogół obywateli do płacenia podatków. Jest ona rezultatem ścisłej więzi pomiędzy społeczeństwem a państwem. Sprzyja temu dobrze rozwinięty system demokracji bezpośredniej oraz niewielki obszar regionów kraju, jakimi są kantony ${ }^{37}$. Podobnie w Szwecji, gdzie mimo wysokich obciążeń podatkowych, zakres szarej strefy jest niewielki. Szwedów charakteryzuje wysoki poziom świadomości społecznej i stosunek do obowiązków obywatelskich.

Postawy polskich podatników są odmienne. W sondażu Instytutu Pentora, obejmującym reprezentatywną grupę tysiąca osób, aż 28\% respondentów, w tym głównie młodych (poniżej 30. roku życia) i prywatnych przedsiębiorców, uznało, że unikający płacenia podatków postępuja jak większość populacji, że takie zachowanie jest codziennością. Co dziesiąty ankietowany uznał takie osoby za ludzi odważnych i przedsiębiorczych. Mniej niż połowa badanych (48\%) postrzegało podmioty ukrywające swoje dochody i unikające płacenia podatków jako oszustów i przestępców ${ }^{38}$.

Wśród Polaków zachowanie polegające na tym, że ktoś narusza wspólne dobro, unikając płacenia podatków, nie wzbudza negatywnych uczuć. Znaczna część społeczeństwa uznaje uchylanie się od obowiązku fiskalnego za powszechnie przyjęte zjawisko oraz za rzecz godną aprobaty. Spadek wrażliwości jest widoczny we wszystkich grupach społecz-

\footnotetext{
${ }^{34}$ A. Klein, Steuermoral und Steuerrecht. Akceptanz als Element einer steuerlichen Rechtferti-gungslehre, Europäischer Verlag der Wissenschaften, 1997, s. 45, cyt. za: A. Gomułowicz, J. Małecki, op. cit., s. 247.

${ }^{35} \mathrm{~J}$. Alm, B. Torgler, op. cit.

${ }^{36} \mathrm{~F}$. Jacob, Taxes are what we pay for a civilized society - moralność i kultura podatkowa na tle amerykańskiego systemu podatkowego, „Monitor podatkowy” 1995/9, s. 2.

${ }^{37}$ L.P. Feld, B.S. Frey, Tax Evasion in Switzerland: The Roles of Deterrence and Tax Morale, Working Paper, Center for Research in Economics, Management and the Arts-CREMA, Basel, 2006/13.

${ }^{38}$ R. Kruszewski, Polacy o podatkach, ,Przegląd Podatkowy” 1992/3, s. 5.
} 
nych, jednak zasadniczym wyznacznikiem jest poziom wykształcenia ${ }^{39}$. Najmniej wrażliwi na naganne zachowania podatkowe są najmłodsi Polacy, a najbardziej - osoby bliskie wieku emerytalnego (45-64 lata). Najmniej wyczuleni na lekceważenie obowiązku podatkowego są osoby mieszkające na wsi, najbiedniejsi, z najniższym wykształceniem ${ }^{40}$.

Ocena moralna uchylania się od podatków nie zawsze musi być jednoznaczna. W Katechizmie Kościoła Katolickiego oszustwa podatkowe uznaje się za moralnie niegodziwe, niemniej jednak znaczenia nabierają okoliczności, w jakich do niedozwolonego czynu dochodzi. Te uwarunkowania wpływają na brak negatywnej oceny. Bernal na podstawie badań kwestionariuszowych wskazuje, że ocena moralna uchylania się od opodatkowania pozostaje $\mathrm{w}$ ścisłym związku z przyczynami skłaniającymi podatnika do popełnienia oszustwa. Według ankietowanych okoliczności, w jakich podatki są nakładane, wymierzane i pobierane, mogą zwalniać podatników z moralnego obowiązku zapłaty podatku ${ }^{41}$.

Wyniki badań psychologów wskazują, że moralność podatkowa Polaków zależy przede wszystkim od subiektywnej oceny sprawiedliwości proceduralnej. Przekonanie podatników, że obowiązujące stawki podatkowe pozwalają na prawidłowe rozłożenie ciężarów podatkowych między poszczególnymi grupami podatkowymi oraz że urzędy skarbowe są przyjazne i uczciwe, powoduje, iż podatnicy w mniejszym stopniu akceptują oszustwa podatkowe. Skłonność do uchylania się od podatków nasila się wraz ze spadkiem poczucia sprawiedliwości. Uchylanie się $\mathrm{w}$ takich warunkach może być widziane jako słuszne działanie w niesłusznej sprawie ${ }^{42}$.

\section{MORALNE UWARUNKOWANIA UCHYLANIA SIĘ OD PODATKÓW W ŚWIETLE BADAŃ WLASNYCH}

W świadomości społecznej niezapłacenie podatku nie jest niczym złym, a skuteczna ucieczka przed nim daje poczucie satysfakcji. Ponadto często w powszechnym przekonaniu podatki są za wysokie i niesprawiedliwe, a prawo podatkowe niejasne i niestabilne. Takie okoliczności zmniejszają poczucie winy w wypadku uchylenia się od podatku.

Badania własne przeprowadzone $w$ latach $2007-2013$ potwierdzają ${ }^{43}$, że oszustwa podatkowe nie są oceniane negatywnie przez znaczną część populacji. W tabeli 1 zaprezentowano strukturę odpowiedzi na pytanie o opinię dotyczącą zatajania dochodów.

\footnotetext{
${ }^{39}$ Bankructwa gospodarstw domowych. Perspektywa ekonomiczna i spoleczna, red. B. Świecka, Difin, Warszawa 2008, s. 107.

${ }^{40}$ Diagnoza spoteczna 2009. Warunki i jakość życia Polaków, red. J. Czapiński, T. Panek, WSFiZ w Warszawie, Warszawa 2009, s. 258.

${ }^{41}$ Takimi okolicznościami były według ankietowanych sytuacje, gdy część pieniędzy pochodzących z podatków przejmowana jest przez skorumpowanych polityków, jeśli rząd dyskryminuje obywateli z powodów religijnych, rasowych. Respondenci także uznali, że oszustwa podatkowe byłyby etyczne, gdyby byli Żydami żyjącymi w nazistowskich Niemczech w 1940 r., gdyby nie było ich stać na zapłacenie podatków. Por. A. Bernal, Zjawisko uchylania się od podatków dochodowych i metody jego ograniczania, Difin, Warszawa 2008, s. 44-46.

${ }^{42}$ M. Niesiobędzka, op. cit., s. 127-130.

${ }^{43}$ Badania własne przeprowadzono na niereprezentatywnej próbie 686 gospodarstw domowych (w maju 2007 r.), 750 gospodarstw domowych (w maju 2009 r.), 1084 gospodarstw domowych (w kwietniu i maju 2010 r.), 1201 gospodarstw domowych (w maju 2011 r.), 1230 gospodarstw domowych (w styczniu 2012 r.) oraz 1128 gospodarstw w styczniu 2013 r. W badaniach ankietowych przeprowadzonych w maju $2007 \mathrm{r}$. wzięły udział gospodarstwa domowe z terenu całej Polski, natomiast wywiady w latach 2009-2013 przeprowadzono na terenie województwa podkarpackiego. Ankiety były skierowane do osób powyżej 20. roku życia o zróżnicowanym poziomie dochodów oraz standardzie życia.
} 
W latach 2007-2011 niemal 30\% osób uważało, że takie postępowanie należy potępić, w 2013 roku już co czwarta osoba była tego zdania. Co roku blisko połowa respondentów usprawiedliwiała oszustwa podatkowe wysokimi daninami. Wzrósł także odsetek osób (z 3,6\% do 6,6\%), które pochwalają zatajanie dochodów, uważając je za przejaw zaradności życiowej.

Tabela 1. Struktura odpowiedzi na pytanie: Co Pan/-i myśli o przypadkach zatajania przez ludzi części swych zarobków w celu zmniejszenia płaconych podatków?

\begin{tabular}{|c|c|c|c|c|c|c|}
\hline \multirow{2}{*}{ Opinia o zatajaniu dochodów } & \multicolumn{7}{|c|}{ Struktura procentowa } \\
\cline { 2 - 8 } & $\mathbf{2 0 0 7}$ r. & $\mathbf{2 0 0 9}$ r. & $\mathbf{2 0 1 0}$ r. & $\mathbf{2 0 1 1}$ r. & $\mathbf{2 0 1 2}$ r. & $\mathbf{2 0 1 3}$ r. \\
\hline $\begin{array}{c}\text { Należy to potępiać, gdyż jest to oszu- } \\
\text { kiwanie państwa }\end{array}$ & $28,1 \%$ & $28,5 \%$ & $28,6 \%$ & $28,8 \%$ & $26,9 \%$ & $24,9 \%$ \\
\hline $\begin{array}{c}\text { Należy to wybaczyć, gdyż podatki są } \\
\text { za wysokie }\end{array}$ & $45,3 \%$ & $39,6 \%$ & $47,5 \%$ & $45,6 \%$ & $43,2 \%$ & $47,7 \%$ \\
\hline $\begin{array}{c}\text { Należy to pochwalić jako przejaw } \\
\text { zaradności }\end{array}$ & $3,6 \%$ & $4,8 \%$ & $4,8 \%$ & $7,6 \%$ & $5,5 \%$ & $6,6 \%$ \\
\hline Trudno powiedzieć & $22,7 \%$ & $24,4 \%$ & $17,8 \%$ & $17,3 \%$ & $23,5 \%$ & $20,2 \%$ \\
\hline Brak odpowiedzi & $0,3 \%$ & $2,7 \%$ & $1,3 \%$ & $0,7 \%$ & $0,9 \%$ & $0,6 \%$ \\
\hline
\end{tabular}

Źródło: obliczenia własne na podstawie przeprowadzonych badań ankietowych z lat 2007-2013

Tabela 2. Opinia o oszustwach podatkowych według wieku i sytuacji dochodowej

\begin{tabular}{|c|c|c|c|c|}
\hline \multirow{2}{*}{ Wiek } & \multicolumn{4}{|c|}{ Opinia o zatajaniu dochodów (\%) } \\
\cline { 2 - 5 } & Potępienie & Wybaczenie & Pochwala & Trudno powiedzieć \\
\hline$<25$ lat & $21,09 \%$ & $50,00 \%$ & $7,42 \%$ & $21,48 \%$ \\
\hline $26-35$ lat & $18,50 \%$ & $51,54 \%$ & $6,61 \%$ & $23,35 \%$ \\
\hline $36-50$ lat & $27,66 \%$ & $48,94 \%$ & $5,96 \%$ & $17,45 \%$ \\
\hline $51-60$ lat & $29,41 \%$ & $44,61 \%$ & $5,88 \%$ & $20,10 \%$ \\
\hline$>60$ lat & $30,46 \%$ & $43,66 \%$ & $7,11 \%$ & $18,78 \%$ \\
\hline Dochody (mies.) & & & & $20,72 \%$ \\
\hline$<600 \mathrm{zl}$ & $23,03 \%$ & $49,34 \%$ & $6,91 \%$ & $23,19 \%$ \\
\hline $601-1000 \mathrm{zl}$ & $23,94 \%$ & $46,63 \%$ & $6,23 \%$ & $18,15 \%$ \\
\hline $1001-2000 \mathrm{zl}$ & $27,05 \%$ & $50,68 \%$ & $4,11 \%$ & $12,75 \%$ \\
\hline$>2000 \mathrm{zl}$ & $32,35 \%$ & $42,16 \%$ & $12,75 \%$ & \\
\hline
\end{tabular}

Źródło: obliczenia własne na podstawie danych z przeprowadzonych badań ankietowych gospodarstw domowych w $2013 \mathrm{r}$.

W tabeli 2 przedstawiono opinie na temat zatajania dochodów według wieku respondentów oraz ich dochodów, przy czym w wypadku obu tych cech nie zaobserwowano istotnej zależności. Bez względu na wiek i poziom zamożności ankietowani tłumaczyli oszustwa wysokimi podatkami. Wraz z wiekiem nieznacznie zwiększa się postawa negująca oszustwa, a minimalnie zmniejsza się skłonność ankietowanych do wybaczania postępowania zagrożonego sankcjami karno-skarbowymi. Z kolei grupa podatników najlepiej zarabiających charakteryzowała się najwyższym odsetkiem osób pochwalających taki proceder, a więc tam, gdzie motywacja do uszczuplenia należności podatkowej jest największa, jest też największa skłonność do oszustw.

Ankietowani w jeszcze większym stopniu usprawiedliwiali uchylanie się od podatków, gdy sami zostali postawieni w hipotetycznej sytuacji braku legalnej pracy (tab. 3). 
W takich okolicznościach na podjęcie pracy nieformalnej zdecydowałoby się w $2012 \mathrm{r}$. 77,0\% osób, a w 2013 r. - 75,2\% gospodarstw domowych (zdecydowanie tak - 43,7\%; raczej tak $-31,5 \%$ ). Jedynie $3,6 \%$ respondentów kategorycznie nie podjęłaby się pracy na czarno, bez względu na uwarunkowania.

Tabela 3. Struktura odpowiedzi na pytanie: Czy gdyby Pan/-i stracił/-a dziś pracę i nie mógł/mogła znaleźć pracy legalnej podjął/podjęłaby się Pan/-i pracy na czarno?

\begin{tabular}{|c|c|c|c|c|}
\hline \multirow{2}{*}{ Opinia } & \multicolumn{2}{|c|}{ Liczba osób } & \multicolumn{2}{c|}{ Struktura procentowa } \\
\cline { 2 - 5 } & 2012 r. & 2013 r. & 2012 r. & 2013 r. \\
\hline Tak & 594 & 493 & $48,3 \%$ & $43,7 \%$ \\
\hline Raczej tak & 353 & 355 & $28,7 \%$ & $31,5 \%$ \\
\hline Raczej nie & 79 & 67 & $6,4 \%$ & $5,9 \%$ \\
\hline Nie & 50 & 41 & $4,1 \%$ & $3,6 \%$ \\
\hline Nie wiem & 131 & 159 & $10,7 \%$ & $14,1 \%$ \\
\hline RAZEM & 1230 & 1128 & $100,0 \%$ & $100,0 \%$ \\
\hline Brak odpowiedzi & 23 & 13 & $1,9 \%$ & $1,2 \%$ \\
\hline
\end{tabular}

Źródło: obliczenia własne na podstawie przeprowadzonych badań ankietowych w latach 2011-2012

Tabela 4. Struktura odpowiedzi na pytanie o postępowanie Pana Kowalskiego w jego trudnej sytuacji życiowej

\begin{tabular}{|c|c|c|}
\hline Opinia & $\begin{array}{c}\text { Liczba } \\
\text { osób }\end{array}$ & $\begin{array}{c}\text { Struktura } \\
\text { procento- } \\
\text { wa }\end{array}$ \\
\hline $\begin{array}{c}\text { Zdecydowanie powinien przyjąć tę ofertę pracy - rodzina jest przecież naj- } \\
\text { ważniejsza i jakoś trzeba ją utrzymać }\end{array}$ & 516 & $45,8 \%$ \\
\hline Raczej powinien przyjać tą propozycję pracy, to zawsze jakieś pieniádze & 293 & $26,0 \%$ \\
\hline $\begin{array}{c}\text { Przeczekać jeszcze jakiś czas, może w tym czasie uda mu się znaleźc pracę } \\
\text { na umowę, lecz gdy się nie pojawi - skorzystać z oferty pracy nieformalnej }\end{array}$ & 192 & $17,0 \%$ \\
\hline Zdecydowanie nie powinien podejmować tej pracy, to nieuczciwe & 32 & $2,8 \%$ \\
\hline Nie mam zdania & 80 & $7,1 \%$ \\
\hline RAZEM & 1128 & $100,0 \%$ \\
\hline Brak odpowiedzi & 15 & $1,3 \%$ \\
\hline
\end{tabular}

Źródło: obliczenia własne na podstawie danych z przeprowadzonych badań ankietowych w 2013 r.

Tabela 5. Struktura odpowiedzi na pytanie: Jak ocenia Pan/-i próby ucieczki przed podatkiem?

\begin{tabular}{|c|c|c|}
\hline Opinia & Liczba osób & $\begin{array}{c}\text { Struktura procen- } \\
\text { towa }\end{array}$ \\
\hline Popieram & 114 & $10,2 \%$ \\
\hline Usprawiedliwione, gdy rodzina nie ma pieniędzy & 520 & $46,1 \%$ \\
\hline Niedopuszczalne & 227 & $20,1 \%$ \\
\hline Nie mam zdania & 243 & $21,5 \%$ \\
\hline RAZEM & 1128 & $100,0 \%$ \\
\hline Brak odpowiedzi & 24 & $2,1 \%$ \\
\hline
\end{tabular}

Źródło: obliczenia własne na podstawie danych z przeprowadzonych badań ankietowych w $2013 \mathrm{r}$. 
Argumentem zmniejszającym rangę czynu zabronionego jest zła sytuacja ekonomiczna i rodzinna podatnika, która może skłaniać do łamania norm prawa. W kwestionariuszu przedstawiono ankietowanym sytuację Jana Kowalskiego (tab. 4), który „,niedawno stracił pracę $\mathrm{i}$ jest bezrobotnym. Ma on na utrzymaniu 6-osobową rodzinę, w której najstarsze dziecko uczy się w szkole podstawowej, a najmłodsze ma 3 miesiące. Pan Jan, jako jedyny żywiciel rodziny, znalazł się w trudnej sytuacji. Otrzymał on jednak ofertę pracy nieformalnej i nie wie, jak ma postąić, gdyż jest bardzo uczciwym człowiekiem. Jak Pan/Pani sądzi, co powinien zrobić Pan Kowalski?". Niemal połowa biorących udział w badaniu uznała, że Kowalski zdecydowanie powinien podjąć nielegalną pracę, kierując się dobrem rodziny. Jedynie $2,8 \%$ ankietowanych potępiało zatrudnienie na czarno (zdecydowanie niższy odsetek osób negowało oszustwa w wypadku bezrobotnego ojca wielodzietnej rodziny).

Wpływ na mentalność podatkową ma odbiór społeczny państwa jako anonimowej instytucji, co rodzi przekonanie, że nikt nie zostanie pokrzywdzony na skutek oszustw podatkowych. Ocena próby ucieczki przed podatkiem spotkała się wśród ankietowanych z 10-procentowym poparciem (tab. 5), 46,1\% osób usprawiedliwiało to sytuacją braku środków do życia, a jedynie co piąty pytany uznał uchylanie się od podatku za niedopuszczalne.

\section{PODSUMOWANIE}

Czynniki historyczne ukształtowały mentalność i moralność Polaków, w tym moralność podatkową. Nie bez znaczenia rolę w kształtowaniu świadomości podatkowej odgrywają czynniki ekonomiczne. Zachowanie jednostki można porównać do zachowania gracza, który wybiera między pewną stratą (zapłacenie całej, należnej kwoty podatku), możliwym zyskiem (nieujawnione oszustwo podatkowe) lub możliwą wysoką stratą (odkrycie uchylanie i nałożenie kary). Podatnicy porównują korzyści, jakie wiążą się z niezapłaceniem podatków z ponoszonym ryzykiem. Wskazuje się, że ryzyko kontroli jest niewielkie, często nie sięga poziomu istotności statystycznej, a mimo to znaczna część osób reguluje swoje zobowiązania podatkowe, co wynika między innymi z ich moralnego obowiązku.

Niepokojące jest to, że z roku na rok rośnie przekonanie, iż oszustwa podatkowe to przejaw zaradności, a co najmniej $40 \%$ osób szuka wytłumaczenia w wysokości obciążeń fiskalnych, czy też w braku środków do życia. Jak wskazują badania, sytuacja, w której dochodzi do uszczuplenia podatkowego, jest wystarczającym usprawiedliwieniem uchylania się od opodatkowania dla wielu spośród ankietowanych, a okoliczności, na przykład problem ze znalezieniem pracy, występują w Polsce coraz częściej.

Żaden system podatkowy nie był nigdy, nie jest i nie będzie oparty na zaufaniu do podatnika i jego sumienia, a opór wobec realizacji obowiązków podatkowych zawsze będzie związany z niechęcią do płacenia danin. Równocześnie należy pamiętać, że obywatel, płacąc podatki, bierze udział w budowaniu wspólnego dobra i korzysta ze świadczeń oraz dóbr oferowanych mu przez państwo. Dopóki jednak system podatkowy będzie widziany jako zbyt restrykcyjny i niesprawiedliwy, dopóty oszustwo fiskalne będzie częściej postrzegane jako akt samoobrony, a nie napiętnowany społecznie czyn karalny sankcjami karno-skarbowymi. 


\section{LITERATURA}

[1] Alm J., Torgler B., Culture differences and tax morale in the United States and in Europe, „Journal of Economic Psychology”, Amsterdam 2006/27.

[2] Bankructwa gospodarstw domowych. Perspektywa ekonomiczna i społeczna, red. Świecka B., Difin, Warszawa 2008.

[3] Bernal A., Zjawisko uchylania się od podatków dochodowych i metody jego ograniczania, Difin, Warszawa 2008.

[4] Bogacka-Kisiel E., Finanse osobiste. Zachowania - produkty - strategie, PWN, Warszawa 2012.

[5] Bywalec Cz., Ekonomika i finanse gospodarstw domowych, PWN, Warszawa 2012.

[6] Diagnoza społeczna 2009. Warunki i jakość życia Polaków, red. Czapiński J., Panek T., WSFiZ w Warszawie, Warszawa 2009.

[7] Feld L.P., Frey B.S., Tax Evasion in Switzerland: The Roles of Deterrence and Tax Morale, Working Paper, Center for Research in Economics, Management and the Arts-CREMA, Basel, 2006/13.

[8] Gaudemet P., Finanse publiczne, PWE, Warszawa 2000.

[9] Głuchowski J., Polskie prawo podatkowe, LexisNexis, Warszawa 2006.

[10] Gołdyn A., Przyczyny ucieczki przed podatkiem, „Monitor Podatkowy” 1996/6.

[11] Gomułowicz A., Małecki J., Podatki i prawo podatkowe, LexisNexis, Warszawa 2004.

[12] Gomułowicz A., Polityka podatkowa w Polsce i przesłanki jej ksztaltowania, „Monitor Podatkowy" 1996/5.

[13] Grzywacz J., Pranie pieniędzy. Metody. Raje Podatkowe. Zwalczanie, Oficyna Wydawnicza SGH, Warszawa 2011.

[14] Gumułowicz A., Zasada sprawiedliwości podatkowej, Dom Wydawniczy ABC, Warszawa 2001.

[15] Gwiazdowski R., Podatek progresywny i proporcjonalny. Doktrynalne przesłanki, praktyczne konsekwencje, Wydawnictwo Uniwersytetu Warszawskiego, Warszawa 2007.

[16] Jacob F., Taxes are what we pay for a civilized society - moralność i kultura podatkowa na tle amerykańskiego systemu podatkowego, „Monitor podatkowy” 1995/9.

[17] James S., Nobes C., The economics of Taxation, Philip Allan, Oxford 1988.

[18] Kichler E., The economic psychology of tax behaviour, Cambridge University Press, Cambridge 2007.

[19] Klein A., Steuermoral und Steuerrecht. Akceptanz als Element einer steuerlichen Rechtfertigungslehre, Europäischer Verlag der Wissenschaften, 1997.

[20] Kliamkin I., Timofiejew L., Szara strefa w Rosji, Cyklady, Warszawa 2003.

[21] Komar A., Finanse publiczne w gospodarce rynkowej, Oficyna Wydawnicza Branta, Bydgoszcz 1996.

[22] Kozłowicz A., Mruk H., Nowaczyk G., Przyczyny i konsekwencje drugiego obiegu dochodów, „Gospodarka Planowa” 1987/6.

[23] Krajewska A., Podatki. Unia Europejska, Polska, Kraje Nadbattyckie, PWE, Warszawa 2004.

[24] Kruszewski R., Polacy o podatkach, „Przegląd Podatkowy” 1992/3.

[25] Mróz B., Gospodarka nieoficjalna w systemie ekonomicznym, Szkoła Główna Handlowa, Warszawa 2002.

[26] Niesiobędzka M., Relacje podatnik - państwo jako predykatory moralności podatkowej, „Psychologia Społeczna", tom 4/3, red. M. Lewicka, Polskie Stowarzyszenie Psychologii Społecznej, Warszawa 2009.

[27] Oręziak L., Konkurencja podatkowa i harmonizacja podatków w ramach Unii Europejskiej. Implikacje dla Polski, WSHiP w Warszawie, Warszawa 2007.

[28] Pietrewicz M., Polityka fiskalna, Warszawa 1993.

[29] Piński J., Trębski K., Zrobieni na szaro, „Wprost” 2003/5. 
[30] Schneider F., Torgler B., Shadow Economy, Tax Morale, Governance and Institutional Quality: A Panel Analysis, „IZA Discussion Paper Series” 2007/2541.

[31] Sufin Z., Spoleczne uwarunkowania i konsekwencje kryzysu, „Nowe Drogi” 1980/12.

[32] Szczodrowski G., Polski system podatkowy, PWN, Warszawa 2007.

[33] Szulc A., Przyczyny i skutki zatrudnienia nierejestrowanego w Polsce, Cedetu, Warszawa 2013.

[34] Taranow I., Socjalno-psychologiczne aspekty uchylania się od podatków na Ukrainie, „Studia i Prace KZiF", z. 22, SGH, Warszawa 2001.

[35] Torgler B., Tax Compliance and Tax Morale. A Theoretical and Empirical Analysis, Edward Elgar Publishing Limited, Cheltenham 2007.

[36] Wiśniewski M., Źródła i rozmiary drugiego obiegu gospodarczego w Polsce, „Ekonomista” $1985 / 6$.

\section{TAX MORALITY AND MENTALITY AS A HOUSEHOLD RESPONSE TO TAXATION}

Taxes take over a part of households income or assets, that is why often it's considered as a factor limiting consumption, investments and the individuals freedom. Taxes deprived of their neutrality generate economic and social impact and thus significantly determine the behavior of market participants. Elements of taxation such as subject, object, tax rates and tax reliefs affect the responses of households with respect to tax liabilities. On the one hand development of civilization, rapid advances in science and technology had a great impact on the quality of life of modern societies, on the other hand also highlights a noticeable drop in public morality.

Taxes are involuntary, non-refundable, they restrict consumption and create a feeling of taxpayer discontent. The article characterizes the attitude of taxpayers and non-economic reasons that may affect the response of household towards tax liability. In economic literature six types of responses of taxpayers are characterized regarding fiscal burden: fulfillment of tax obligations, flip tax, legal tax avoidance, catch, illegal tax avoidance and withdrawal from activities covered by the tribute. The purpose of this article is to present the essence of morality and mentality of Poles and their fiscal impact on the tendency of households to avoid taxes.

Keywords: tax morality, tax mentality, tax fraud

DOI: 10.7862/rz.2013.mmr.8

Teks złożono w redakcji: styczeń 2013

Przyjęto do druku: czerwiec 2013 